\title{
Tripartite Motif-Containing Protein 5
}

National Cancer Institute

\section{Source}

National Cancer Institute. Tripartite Motif-Containing Protein 5. NCI Thesaurus. Code C98163.

Tripartite motif-containing protein 5 (493 aa, $\sim 56 \mathrm{kDa}$ ) is encoded by the human TRIM5 gene. This protein plays a role in the cellular defense against viral infection. 